\title{
Integrating Entrepreneurial Education Skills in Social Studies Pedagogy for Poverty Reduction and Sustainable Development in Nigeria
}

\author{
Ogene A. Oyibe \\ Department of Arts \& Social Science Education, Ebonyi State University, Abakaliki, Nigeria \\ E-mail: buikeoyibe@gmail.com \\ P. E. Eluu \\ Department of Arts \& Social Science Education, Ebonyi State University, Abakaliki, Nigeria \\ E-mail: eluupat@gmail.com
}

Received: January 12, 2014 Accepted: January 23, 2014 Published: February 8, 2015

doi:10.5296/jet.v2i1.7063 URL: http://dx.doi.org/10.5296/jet.v2i1.7063

\begin{abstract}
The thrust of this paper focused on integrating entrepreneurial education skills in Social studies pedagogy for poverty reduction and sustainable development in Nigeria. Nigeria as sovereign nation has a persistently high rate of poverty, unemployment, insecurity and other problems that need practical oriented solution. Despite the laudable financial demanding strategies put forward by the Nigerian government, at most $70 \%$ of Nigerian citizens still live below poverty level. These socio-economic problems call for sustainable diverse strategies and actions for them to be ameliorated. It the researchers' opinion that integrating entrepreneurial education skills in Social studies pedagogy will render tremendous assistance in wealth creation and jobs among unemployed Nigerians for self reliance thereby reducing poverty and maintaining sustainable national development. In this paper, the relevance of integrating entrepreneurial education skills in Social studies pedagogy for poverty reduction and sustainable development were discussed and recommendations were made.
\end{abstract}

Keywords: Entrepreneurial Education, Social Studies, Poverty Reduction and Sustainable Development 


\section{Introduction}

Nigeria as a sovereign nation is endowed by nature with both human and material resources, yet a large proportion of her human population live below one United State of America dollar (\$1) per day. The socio-economic situation of the Nigerian citizen is at its declining rate not minding increasing revenue generation from crude oil.

Indication of poverty has been one of the major problems facing developing countries of the world like ours (Nigeria) where the economic conditions of most families have declined to alarming rates. Every year, thousands of young Nigerians graduate from different institutions of higher learning. These young people move from one office to another in search of non-existing jobs. Sometimes, an insignificant percentage of these graduates succeed in actually getting employment while others remain unemployed which result to poverty. Ali (2002), opined that poverty is defined as ones inability to acquire and use or have access to the most basic essentials of life usually because of poor income earning, handicapping conditions or government inability to provide such essentials like food, clothing, shelter, water, transportation and work. Akamobi and Akabueze (2002) added that poverty is a state of one being difficult in social and economic needs that make for a good living because of poor income earning. In the same line of thought, Molokwu (2010) noted that poverty is the inability to provide the basic necessities of life like food, water shelter and clothing". All the above definitions are the traditional perspectives of poverty where emphasis is on income or its value as regard to human wants.

The traditional perspective of poverty is limited to the economic sphere, mainly income or its socio-economic value. This has adversely affected a clear comprehension of the concept (poverty) viewed as a phenomenon or a situation. Lending support to the above view, Adirika, (2010:128) however was of the view that, "at present the concept of poverty has moved from the emphasis on income poverty to a multidimensional concept that includes other areas of life". He thus defines poverty as "a state of inability to possess the appropriate needs required for a healthy and meaningful living in society", (Adirika, 2010:128). These things required for a healthy and living could be good education, good housing, self-esteem, among others; they are not limited to man's income in its strict sense.

For global comprehension and analytic purposes, the concept poverty should be viewed from multidimensional perspective, the United Nations Development Programme (UNDP), (1994:3) defined poverty as multidimensional and global phenomenon characterized by food insecurity of absolute or relative forms, lack of access to health services, poor or inadequate education, lack of basic needs such as shelter, clothing, sanitation, as well as physical and psychological experience of violence. These basic requirements for essential healthy living are not restricted to economic sphere but extend to social, cultural, political and spiritual understanding of man's existence. This informed Ezeji's assertion in Ndem (2010:17) that "poverty is the state of living in which individual or group is faced with economic, social, political, cultural and environmental deprivations". This has implications for Social studies education since it is referred to as a subject matter, possessing skills, attitudes and activities that focus on society and individuals as members of a social group. National Teachers' 
Institute (N.T.I,2000), opines that Social studies is an area of school curriculum specifically designed for the study of man and how he fits into the society by utilizing the necessary attitudes, values and skills at his reach.

The high level of poverty in Nigeria had given birth to a lot of deviant behaviours and these include bribery, corruption, fraud, prostitution, lawlessness, armed robbery, ritual killings, stealing by tricks (419), drug pushing, child trafficking, kidnapping, terrorism among others. It is not over statement for one to out rightly say that Nigerians lack almost every basic necessity for meaningful living. Food insecurity, lack of access to health services, poor education, shelter and poor environmental cleanness that characterized Niger Delta region in Nigeria resulted kidnapping and hostage taking of oil workers in zone. Again, inadequate education and lack of basic needs such as shelter, clothing, good water, as well as physical and physiological experience of violence melted on poor young people popularly known as almajeri in the Northern Nigeria can be digest as one of the reasons that fueled Boko Haram activities of bombing and killing in the zone.

In order to reduce poverty and these deviant behaviours, Nigeria like many other developing countries of the world launched her poverty alleviation programme (PAP) on the $14^{\text {th }}$ day of February, 2000 (Onu and Akamobi, 2010). In line with the above, Odukwu (2001) was of the view that hug sum over ten billion naira was allocated to the programme by federal government of Nigeria under Obasanjo's administration and it was aimed at reducing under-nourishment/malnourishment, under-clothing, ignorance and poor health. He finally submitted that poverty alleviation programme (PAP) was a well articulated and laudable programme but its demise was as a result of shoddy implementation when the objectives of PAP cannot be achieved, the federal government later changed it to National Poverty Eradication Programme (NAPEP) aimed at combating poverty and food crisis at family level in order to improve the living condition of the citizenry. Among the NAPEP's poverty eradication initiatives are:
a. Keke NAPEP
b. Coping with Poverty Eradication (COPE)
c. Conditional Cash Transfer (CCT)
d. Poverty Reduction Accelerator Investment (PRAI)

Keke NAPEP: It is an experimental model of poverty eradication that seeks to empower the poor employed or unemployed Nigerians to a position where they can create a measurable and verifiable value in order to earn a living (Adigun, 2011).

COPE: It is Nigeria's version of the globally acceptable conditional cash transfer (CCT) which is social safety nets programmes aimed at improving the conditions of living of the poor in society. COPE entails the provision of grants to targeted poor households on the condition of investment in human capital development (Alaueme, 2011).

In the programme, conditional cash transfers are made to identified individuals or households on the condition that they abide by certain stipulations. These conditions are tied to human 
capital development in the area of education and health care. Adigun (2011) noted that CCT programmes provide cash payments to poor households that meet certain behavioural requirements generally related to children's health care and education.

Despite these efforts and programmes initiated by federal government of Nigeria in order to eradicate poverty or in other words reduce it a bearable rate, the percentage of poor Nigerians that is those living below the equivalent of one United States of America (USA) dollar still stands at about $70 \%$ of the total population of Nigeria. The inability of the federal government to actualize her objectives for initiating these programmes should be attributed to poor information and communication on business transaction skills between the organizers and the participants. It is the researchers' opinion that if these entrepreneurial strategies and skills initiated by the federal government of Nigeria were integrated in Social studies pedagogy, there would be a proper flow of communication between the organizers and targeted participants.

\section{Developing Supportive Entrepreneurial Skills in Social studies for Poverty Reduction}

Entrepreneurial education according to pribadi (2005) referred to training to develop entrepreneurial attitudes and skills which involves developing certain personal qualities focused on creation of new business and how to minimize the failure or risk of being entrepreneur. According to Liles in Nwosu, Oforka, and Omeje (2010), the entrepreneurial risk includes: financial risk, career risk, family risk; social risk and psychic risk. Effective instructional pedagogy is the only instrument needed by the young entrepreneurs in order to reduce these risks to bearable rate. This informs the view of Oyibe (2006) that effective pedagogy is the one aimed at developing intellectual capacity and values for the survival of individuals, providing enabling and conducive environment for the acquisition of both physical and intellectual skills that will enable individuals to be self-reliant and contributive members of their society.

In Nigeria today, Social studies is recognized as a well focused, broad curriculum offering conceptualized as an integrated area of study designed to produce effective citizens and by its nature as an interdisciplinary subject, Social studies education found concrete expression in its usefulness for socio-economic development as well as the right attitudes and skills for utilization of environmental resources for survival of man. Utulu, Shaibu and Mohammed (2012) maintained that in order to reduce probability business failure and thereby fighting poverty. These skills and techniques which can be acquired through formal education like finance (funds), marketing, forecasting, supply chain, logistic, statistic among others. In addition, Linan (2004) opined that the following entrepreneurial education should be integrated into instructional pedagogy for individuals who wish to increase the skills and attitudes of entrepreneurship for a reason of increase their economic status. These include:

- Entrepreneurial awareness education: This type of education focuses mainly on increasing the awareness of entrepreneurial knowledge among people which will not directly pursue the creation of more entrepreneurs but have the knowledge to maintain and manage the existing resources for economic stability. 
- Education for start-up-business: This consists of the preparation to be the owner of a small conventional business. The course will consist of the practical aspects related with the start-up phase on how to obtain financing (loan), legal regulation, taxation among others, (linan, 2004). In line with the above, Adirika (2010) maintained that small scale business is an avenue where the manager start from scratch to create large scale business with the foundation entrepreneurial built from unknown to known. In addition, Adigun (2011) stated that education for with entrepreneurial skills and attitudes for wealth creation.

- Education for entrepreneurial dynamism: This type of entrepreneurial education focuses not only to raise the intention to be an entrepreneur, rather the intention to develop dynamic behaviour when the business is already in operation. This type of entrepreneurial education is meant to equip managers of business enterprise with the managerial principle of wealth creation and risk management for business success.

- Continuing Education for Entrepreneurs: This type of education is a special education for adults, designed to allow improvement of the existing entrepreneur's abilities (Weinrauch in Nwosu et al, 2010). Other entrepreneurial education or training given to students in formal schooling accordance to Nwosu et al (2010) induces creating career awareness, organizing career week or going for a field-trip in industries, internship training or going for industrial attachment in an industry related to the field of study, vocational training such as practical work of constructing a project. These entrepreneurial education or training is a transformational tool and formidable strategies for poverty reduction among Nigerian citizenry. NPC (2005) noted that entrepreneurial education is one of the functional educations that will help to achieve the goals of wealth creation, employment generation, value reorientation, poverty eradication and sustainable development.

Poverty reduction is wealth creation and helping the poor to step out of poverty. However, for effective achievement of poverty eradication programme objectives, Onibokun and Kumuji (1992) suggested that provision of adequate food, stable and healthy shelter, affordable transportation, gainful employment, basic health services basic literacy, basic human rights to life, accessibility to recreational opportunities as strategies for poverty eradication geared toward sustainable national development. In support of the above, Onu and Akamobi (2010) opined that the above strategies may to some extent be difficult to achieve bearing in mind the socio-economic condition of the country as related to education and business activities. On the other hand, Idris in Chidebehu (1999) stated that poverty is best eradicated by directly supporting the productive activities of the poor thereby creates a fairer economic environment to enable them to perform better. This call for integration of entrepreneurial education skills in teaching and learning processes at all levels of Nigerian educational system since it is the type of education that prepares the participants for employment either by self or cooperate organization in a designed occupation. 


\section{Integrating Entrepreneurial skills in Social studies for Sustainable National Development}

Anadi (2006) described sustainable national development as the prolonged and continued movement of a nation towards social justice, economic growth, religious tolerance, political dynamism and technological advancement. Sustainable development according Okpala (2000) is hinged on three related concepts which include service, qualities and productivity.

Entrepreneurial education is therefore the education that prepares young people and adults for employment in specific occupation or family occupation and taking charge of the management of small or large scale business by providing those experiences which will enable them to develop the competences needed to qualify for employment. And Social studies provides enabling and conducive environment where the entrepreneurial skills will be practically displayed for sustainable national development. The acquisition of the appropriate skills and competencies, mentally and physically through a well focused instructional programme as Social studies education will equip people to live in and contribute effectively to the development of their society. Integration of entrepreneurial skills in Social studies pedagogy prepares individuals into business world rather than waiting for white collar job and teaches them how to handle their own business affairs intelligently as operators and consumers in the economy.

Linan (2004), maintained that proper integration of entrepreneurial skills in Social studies pedagogy will enable students develop the understanding, acquire skills and attitudes which will enable them enter into business world and earn living. In addition, Nwosu et al (2010) opined that integration of entrepreneurial education skills in Social studies pedagogy at all levels of education will bring about improvement in skill acquisition and provision of working capital/loan or fund that will help in full utilization of these skills in poverty reduction and sustainable national development.

In the same Vein, Adirika (2010) was of the view that entrepreneurial development through integration of entrepreneurial skills and attitudes in varied facets of educational pursuits provides the key to rapidly addressing the issues of chronic unemployment and lack of jobs currently plaguing graduates of Nigerian universities. Effective integration of entrepreneurial education skills in Social studies pedagogy will inculcate entrepreneurial skills, attitudes and knowledge that would help graduates to be self-reliance. Integrating entrepreneurial education sills is an instrument for change and national development, a provider of service oriented skills that will play a vital role in the economic survival of the nation for sustainable national development.

\section{Conclusion}

The rate of poverty in Nigeria today has raise to alarming stage and its effect is malnutrition and increase in cursive rate. Most rural dwellers are good entrepreneurs at subsistence level. What they need is the type of education that will provide them with the skills and knowledge to expand their business world for poverty reduction and sustainable development and call for integration of entrepreneurial education skills in Social studies pedagogy with the hope such 
will lead to development business skills, improve on them, making them active and compatible with their desire to own and manage business venture as a source of poverty reduction and for sustainable national development.

\section{Recommendations}

- The study recommends that there is urgent need for full integration of entrepreneurial education skills in Social studies pedagogy at all level of education by the ministry of education.

- There is need for refocusing Social studies curriculum for full integration of entrepreneurial skills for poverty reduction and sustainable national development.

- Proper awareness should be created by the government through different media about entrepreneurial education in generating employment and reducing poverty through instructional pedagogy.

\section{References}

Adigun, O. (2011). Poverty Alleviation: South Korea donates Cassava Processors. Daily Sun Tuesday March $8^{\text {th }}$, p. 46.

Adirika, B. N. (2010). Girl-child Education for poverty Alleviation: Consideration of the First at Risk. Journal of Forum for African Women Educationists, 2(1), 128-138.

Akamobi, I., \& Akabueze, I. F. (2002). Strategies for improving manpower in Vocation Education for Poverty Alleviation and Sustainable National Development. Journal of Research in Science and Technology Education. Enugu: university of Science and Technology (ESUT).

Alaueme, E. (2011). Science, Technical and Mathematics Education as a tool for Poverty Alleviation. Unpublished. A lecture presented at the $10^{\text {th }}$ Anniversary Celebration of F.C.E (T) Umunze.

Anadi, C. C. (2006). Governments and Education in Nigeria Concerns for Sustainable national development. A lead paper presented at the Annual Conference of Institute of Education, University of Benin $14^{\text {th }}-18^{\text {th }}$ November, 2006.

Chidebelu, S. (1999). The Challenges of Refits towards Poverty Alleviation in the next millennium. Unpublished key note address presented at the $14^{\text {th }}$ Annual South-East zonal farming system Research and extension workshop Nov. 9-12.

Linan, F. (2004). Intention-based models of entrepreneurship education. Napoly. $14^{\text {th }}$ Annual Int Ent Conference.

Molokwu, N. P. (2010). Rural Poverty among female-headed households: A lesson for the girl-child. international journal of forum for African women educationists, 2(1), 10-30.

Mukhtar, S. M., \& Redman, J. (2004). Development in Eu/uk entrepreneurship / enterprise education policy. Current debate and implications. Institute for small business Affairs. 
Retrieved from www.fpb.co.uk

National planning Commision. (2005). National Economic Empowerment and Development Strategy. (NEEDS) Central Bank of Nigeria.

Ndem, J. U. (2004). Small scale poultry production techniques. In Agricultural Education for Poverty Reduction and Sustainability in the families. Nigerian Journal of Home-Economics, 2(1), 71-79.

Nwosu, E. N., Oforka, T. O., \& Omeje, J. C. (2010). Gender Perception of the utilization of Entrepreneurial education for youth empowerment. International Journal of Educational Research, 10(2), 46-58.

Odukwo, C. A. (2001). Sustainable livestock production and poverty alleviation. Paper presented at Annual conference of the National Association of Livestock Husbandry Scientist and technologists. Awka: January 18-19.

Okpala, M. C. (2000). New Business for African entrepreneurs. Enugu: Ogis venture.

Onibokun, A. G., \& Kumugi, A. J. (1992). Urban poverty in Nigeria: Towards sustainable strategies for its Alleviation. Centre for African settlement studies and development (CASSAD) Monograph series 10.

Onu, F. M., \& Akamobi, I. (2010). Entrepreneurial skills required for success in poultry production: A strategy towards poverty reduction. International Journal of Educational Research, 10(2), 38-45.

Onyekanwa, C. E. (2007). Entrepreneurship in food and chemical industries. Enugu: Institute for Development studies. University of Nigeria Enugu Campus.

Oyibe, O. A. (2006). Teachers' opinion on the ways of improving Social studies pedagogy in secondary schools in Ikwo Local Government Area of Ebonyi State. An unpublished B.Ed Project, Ebonyi State University, Abakaliki.

Pribadi, H. (2005). Defining and constructing the teaching model of entrepreneur education based on entrepreneurial intention model. Petra Christian University Surabaya.

Soo, J. M. (1999). “Made not born”. Entrepreneur of the Year Magazine, fall p. 80

United Nation Development Programme. (1994). Human Development Report. New York: Oxford Press.

\section{Copyright Disclaimer}

Copyright reserved by the author(s).

This article is an open-access article distributed under the terms and conditions of the Creative Commons Attribution license (http://creativecommons.org/licenses/by/3.0/). 